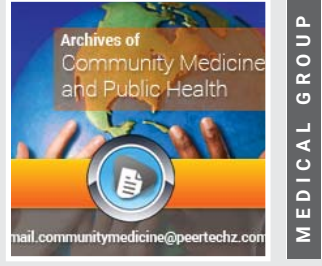

\title{
Higher education and
}

\section{COVID-19: An overview of the most important challenges}

\section{Mahdieh Motie, Seyed Meysam Mousavi², Zahra Sarabandi ${ }^{3}$, Reza Dehnavieh ${ }^{4}$ and Khalil Kalavani ${ }^{5 *}$}

${ }^{1} \mathrm{MSc}$, Student in Nursing, Faculty of Nursing, Islamic Azad University of Tehran, Tehran, Iran

${ }^{2}$ Assistant Professor of Health Policy, Management and Leadership in medical Education Research Center, Kerman University of Medical Sciences, Kerman, Iran

${ }^{3} \mathrm{MSc}$ of Healthcare Management, Management and Leadership in medical Education Research Center, Kerman University of Medical Sciences, Kerman, Iran

${ }^{4}$ Associate Professor of Health Services Management, Head of Innovation Center, Institute for Future Studies in Health, Kerman University of Medical Sciences, Kerman, Iran

${ }^{5} \mathrm{PhD}$, Student in Health Services Management, Faculty of Healthcare Management, Student Research Center, Kerman University of Medical Sciences, Kerman, Iran

The COVID-19 pandemic has caused many disruptions in face-to-face learning, and the use of distance learning has affected all students and teachers [1]. There are a few quantitative studies conducted on the consequences of the COVID-19 virus and its impact on indoors environments such as university. In indoors environments with low ventilation, the virus has the capacity to linger for longer before being inhaled or falling to a surface, which could result in transmission. In enclosed environments, low humidity, air conditioning, and low UV light may all contribute to longer survival of viral particles. Finally, indoor environments may increase host susceptibility. For these reasons, the risk of virus transmission is higher in indoor spaces such as the university [2]. Also, the epidemic has caused all students to encounter rapid and numerous changes. On the other hand, students are looking for their academic and career progress. Although the changes caused by COVID-19 in the field of education may seem minor compared to other changes, they can make a turning point in the academic progress of students [3,4]. Therefore, students need to be prepared for the challenges of the new situation. Given that there is not much information on the challenges and long-term effects of COVID-19 in medical education [5,6], it seems necessary to examine the challenges and effects. This article addressed the most important challenges in the field of education during COVID-19:
Received: 11 January, 2021

Accepted: 25 January, 2021

Published: 27 January, 2021

*Corresponding authors: Khalil Kalavani, PhD, Student in Health Services Management, Faculty of Healthcare Management, Student Research Center, Kerman University of Medical Sciences, Kerman, Iran, Tel: +989373259329; E-mail:k.kalavani@kmu.ac.ir

https://www.peertechz.com

\section{Check for updates}

1. Currently, there are no comprehensive quality assurance systems for online teaching and learning.

2. Online education causes a small number of students to attend the meeting and unlike face-to-face meetings, students rarely speak; the sessions are teacher-centered and the teacher mainly presents the contents using the PowerPoint.

3. A serious challenge that medical students are facing is the cancellation of internships that is necessary both to gain skills and to build relationships.

4. Simulation may be used in the short term, but in the long run, students' academic needs and experiences will face a serious challenge.

5. The opportunity to attend the field of work, direct practices, and acquiring necessary skills is lost.

6. It is not possible to assess the perception of the audience in video conferences.

7. Students' absences have increased.

8. It is difficult to evaluate the effectiveness of new educational methods, including online lectures, and 
there is no certainty that digital and face-to-face models are as effective.

9. Students' socio-economic differences and even their gender have affected the quality of learning in the current situation.

10. Understanding the tone of people's voices, their writings, and even their pictures on the screen without real presence and eye contact is also a challenge.

11. Loss of shared experiences may occur and this can be a significant detriment to education.

Students and faculty should be aware of these challenges and increase their resilience and adaptability in the current situation so that they can successfully overcome such a difficult condition.

\section{Consent to publish}

All authors have read the final manuscript and have given their approval for the manuscript to be published in its present form.

\section{References}

1. Rajab MH, Gazal AM, Alkattan K (2020) Challenges to online medica education during the COVID-19 pandemic. Cureus 12: e8966. Link: https://bit.ly/2YfPzwX

2. Wei J, Li Y (2016) Airborne spread of infectious agents in the indoor environment. Am J Infect Control 44: S102- S 108. Link: https://bit.ly/36f5QGT

3. Ahmed $H$, Allaf M, Elghazaly $H$ (2020) COVID-19 and medical education Lancet Infectious Diseases. Link: https://bit.ly/36gv7QM

4. Ferrel MN, Ryan JJ (2020) The impact of COVID-19 on medical education Cureus 12: e7492. Link: https://bit.ly/3om1Dr1

5. Tabatabai S (2020) COVID-19 impact and virtual medical education. J Adv Med Educ Prof 8: 140-143. Link: https://bit.ly/39nCic6

6. Hilburg R, Patel N, Ambruso S, Biewald MA, Farouk SS (2020) Medical education during the COVID-19 pandemic: learning from a distance. Adv Chronic Kidney Dis 27: 412-417 Link: https://bit.ly/3iR7d3r

\footnotetext{
Discover a bigger Impact and Visibility of your article publication with Peertechz Publications

Highlights

* Signatory publisher of ORCID

* Signatory Publisher of DORA (San Francisco Declaration on Research Assessment)

* Articles archived in worlds' renowned service providers such as Portico, CNKI, AGRIS, TDNet, Base (Bielefeld University Library), CrossRef, Scilit, J-Gate etc.

* Journals indexed in ICMJE, SHERPA/ROMEO, Google Scholar etc.

- OAI-PMH (Open Archives Initiative Protocol for Metadata Harvesting)

* Dedicated Editorial Board for every journal

* Accurate and rapid peer-review process

* Increased citations of published articles through promotions

* Reduced timeline for article publication

Submit your articles and experience a new surge in publication services (https://www.peertechz.com/submission).

Peertechz journals wishes everlasting success in your every endeavours.
} 